\title{
Pengaruh Hubungan Kerja, Motivasi, Kompensasi Dan Pengembangan Karier Terhadap Kinerja Karyawan Pada RSUD. Dr. Muhammad Zein Painan
}

\author{
Della Asmaria Putri \\ Universitas Putra Indonesia YPTK Padang, Indonesia \\ E-mail: dellaasmariaputri03@upiyptk.ac.id
}

\begin{abstract}
Abstrak
Tujuan dari penelitian ini adalah untuk mengetahui adanya Pengaruh Hubungan Kerja, Motivasi, Kompensasi dan Pengembangan Karier terhadap Kinerja Karyawan pada RSUD Dr. Muhammad Zein Painan. Penelitian ini terdiri dari empat variabel yaitu hubungan kerja, motivasi, kompensasi, dan pengembangan karier dan satu variabel dependent kinerja karyawan. Analisis data yang dilakukan adalah dengan menggunakan uji validitas, reliabilitas, regresi linear berganda, Uji F dan Uji t. Pengujian tersebut dilakukan guna untuk mengetahui pengaruh variabel terhadap varibel terikat. Metode pengumpulan data pada penelitian ini adalah dengan menggunakan kuesioner yang diisi oleh responden yaitu Karyawan pada RSUD Dr. Muhammad Zein Painan. Berdasarkan hasil penelitian ini menemukan bahwa hubungan Kerja Motivasi, Kompensasi dan Pengembangan Karier berpengaruh positif dan signifikan terhadap Kinerja Karyawan pada RSUD Dr. Muhammad Zein Painan.
\end{abstract}

Kata kunci: Hubungan Kerja, Motivasi, Kompensasi, Pengembangan Karier, Kinerja.

\section{Pendahuluan}

Perusahaan mempunyai tujuan untuk meningkatkan efisiensi dan kemampuan untuk bertahan dalam daya saing pada era sekarang ini. Agar tujuan perusahaan tercapai dibutuhkan sumber daya manusia yang kompeten dan mempunyai motivasi tinggi. Pentingnya peran sumber daya manusia memiliki tujuan untuk memajukan perusahaan (Hasibuan, 2013). Perusahaan membutuhkan sumber daya manusia yang berkualitas, baik di masa sekarang hingga masa yang akan datang. Suatu perusahaan tidak akan mampu berkompetisi jika karyawannya hanya melaksanakan pekerjaan yang menjadi tanggung jawabnya saja. Fenomena pengangguran, pemutusan hubungan kerja, demonstrasi dan unjuk rasa merupakan masalah kondisi ketenagakerjaan di Indonesia yang masih marak terjadi. Hal tersebut merupakan akibat dari ketidakpuasan dalam berbagai faktor seperti ketidaksesuaian dalam pemberian kompensasi, upah, tunjangan, rewads dan ketidaksesuaian prosedur pemberian imbalan dengan kebijaksanaan perusahaan. Adapun salah satu masalah yang banyak dihadapi oleh perusahaan jasa maupun manufaktur, organisasi profit maupun non profit adalah bagaimana meningkatkan kualitas hasil kerjanya dengan sumber daya yang ada, terutama sumber daya manusia yang merupakan asset yang tidak bisa dibeli (Gunawan, 2017).

Manajemen SDM adalah suatu bidang manajemen yang khusus mempelajari hubungan dan peranan manusia dalam organisasi. Motivasi menurut (Kadarisman, 2014)adalah suatu proses dimana kebutuhan-kebutuhan mendorong seseorang untuk melakukan serangkaian kegiatan yang mengarah ke tercapainya tujuan tertentu. Tujuan yang jika berhasil dicapai, akan memuaskan atau memenuhi kebutuhan-kebutuhan tersebut.

Kompensasi menurut (sofyand, 2013)merupakan suatu bentuk biaya yang harus dikeluarkan oleh perusahaan dengan harapan bahwa perusahaan akan memperoleh imbalan dalam bentuk prestasi kerja dari karyawannya (sudah barang tentu bahwa prestasi kerja yang diberikan karyawan harus lebih besar daripada kompensasi yang dikeluarkan oleh perusahaan).

Pengembangan Karier menurut (Kadarisman, 2014) adalah proses dan kegiatan mempersiapkan seorang karyawan untuk menduduki jabatan dalam organisasi atau perusahaan, yang akan dilakukan dimasa mendatang. 
Tabel 1. Data Kehadiran Karyawan

\begin{tabular}{ccccccc}
\hline Bulan & $\begin{array}{c}\text { Jumlah } \\
\text { Karyawan } \\
\text { (orang) }\end{array}$ & $\begin{array}{c}\text { Hadir } \\
\text { tepat } \\
\text { waktu }\end{array}$ & $\begin{array}{c}\text { Keterangan } \\
\text { Alpha }\end{array}$ & $\begin{array}{c}\text { Terlamb } \\
\text { at }\end{array}$ & Sakit & Izin \\
\hline April & 516 & 316 & 50 & - & 9 & 20 \\
Mei & 516 & 461 & 65 & 17 & 5 & - \\
Juni & 516 & 479 & 45 & 20 & 7 & 15 \\
Juli & 516 & 289 & 23 & 2 & - & 11 \\
Agustus & 516 & 376 & 67 & 18 & 15 & 9 \\
\hline
\end{tabular}

Sumber: RSUD. DR. Muhammad Zein Painan

Dilihat dari table 1 bahwa indikator utama yang diteliti adalah alpha dan keterlambatan pegawai, dapat dilihat tingkat alpha dan keterlambatan masih berfluktuasi, pada bulan april alpha 50 orang, mei alpha 65 orang dan terlambat 17 orang, juni alpha 45 orang dan terlambat 20 orang, juli alpha 23 orang dan terlambat 2 orang, agustus 67 orang alpha dan 18 orang.

Disimpulkan bahwa tingginya tingkat absensi pegawai yang mengalami fluktuasi setiap bulannya yang dilihat berdasarkan tingkat absensi pegawai yaitu alpha dan keterlambatan pada RSUD. Dr. Muhammad Zein Painan masih belum dapat mencapai aspek kinerja pegawai yang optimal, hal ini disinyalir disebabkan masih kurangnya tingkat hubugan kerja, motivasi, kompensasi dan pengembangan karier pada karyawan.

Dari uraian di atas penulis tertarik untuk melakukan penelitian di RSUD Dr. Muhammad Zein dengan topik penelitian tentang "Pengaruh Hubungan Kerja, Motivasi, Kompensasi dan Pengembangan Karier terhadap Kinerja Pegawai pada RSUD Dr. Muhammad Zein Painan".

\section{Tinjauan Pustaka}

\section{Hubungan Kerja}

Hubungan kerja merupakan hubungan kerjasama antara semua pihak yang berada dalam proses produksi di suatu perusahaan atau organisasi (Sagala, 2009).

Adapun Indikator hubungan kerja :

1. Komunikasi karyawan

2. Disiplin

3. Konseling

\section{Motivasi}

Menurut (Ardana, 2012) Motivasi adalah kekuatan yang mendorong seseorang untuk melakukan suatu tindakan atau tidak pada hakekatnya ada secara internal dan eksternal yang dapat positif atau negative untuk mengarahkannya sangat bergantung kepada ketangguhan sang manajer .

Menurut (Didit, 2013), indikator motivasi yaitu:

1. Kebutuhan terhadap prestasi

2. Kebutuhan terhadap kekuasaan

3. Kebutuhan terhadap afiliasi

\section{Kompensasi}

Menurut (Kadarisman, 2014)Kompensasi dimaksudkan sebagai sesuatu yang diterima oleh pekerja sebagai balas jasa atas kerja mereka.

Menurut (Rivai, 2011) indikator kompensasi sebagai berikut :

1. Gaji

2. Upah

3. Insentif

4. Kompensasi Tidak Langsung (Fringe Benefit) 


\section{Pengembangan Karier}

Menurut (Siagian, 2015), pengembangan karier adalah keputusan yang diambil sekarang tentang hal-hal yang akan dikerjakan di masa depan, berarti bahwa seseorang yang sudah menetapkan rencana kariernya, perlu mengambil langkah-langkah tertentu guna mewujudkan rencana tersebut.

Indikator Pengembangan Karir menurut (Sagala, 2009), yaitu terdiri atas beberapa hal :

1. Prestasi kerja

2. Eksposur

3. Jaringan kerja (Net Working)

4. Pengunduran diri

5. Kesetiaan pada organisasi

6. Pembimbing dan sponsor

7. Pengalaman internasional

\section{Hubungan Hubungan Kerja dengan Kinerja Karyawan}

Penelitian yang dilakukan oleh (Ernawati, 2010) yang berjudul "Pengaruh Hubungan Kerja Dan Lingkungan Kerja Terhadap Kinerja Pegawai Dengan Motivasi Kerja Sebagai Varibel Moderating". Berdasarkan penelitiannya variabel hubungan kerja berpengaruh signifikan terhadap kinerja pegawai. Hal tersebut dikarenakan hubungan kerja ada kaitannya dengan kinerja karyawan. Hubungan kerja menjadi pedoman memberikan kenyamanan kepada karyawan ataupun pekerjanya.

\section{Hubungan Motivasi dengan Kinerja Karyawan}

Penelitian yang dilakukan oleh (Gusnita, 2012) yang berjudul " Pengaruh Motivasi dan Ability Terhadap Kinerja Karyawan PT. Jasa Raharja (Persero)". Berdasarkan penelitiannya variabel motivasi berpengaruh signifikan terhadap kinerja karyawan. Hal ini membuktikan dengan adanya motivasi karyawan menjadi semakin bersemangat dalam menyelesaikan pekerjaannya. Oleh karena itu, meningkatkan motivasi sangat penting dalam meningkatkan kinerja perusahaan.

\section{Hubungan Kompensasi dengan Kinerja Karyawan}

Penelitian yang dilakukan oleh (Utami, 2018) yang berjudul "Pengaruh Kompensasi Dan Pengembangan Karir Terhadap Organizational Citizenship behavior (OCB)". Berdasarkan penelitiannya variabel kompensasi berpengaruh signifikan terhadap kinerja karyawan. Hal ini menunjukkan bahwa semakin besar kompensasi yang diberikan perusahaan maka semakin meningkat pula kinerja karyawan.

\section{Hubungan Pengembangan Karir dengan Kinerja Karyawan}

Penelitian yang dilakukan oleh (Syaiful Bahri, 2017) yang berjudul "Pengaruh Pengembangan Karir Dan Motivasi Kerja Terhadap Kepuasan Kerja Karyawan". Berdasarkan penelitiannya variabel pengembangan karir berpengaruh signifikan terhadap kinerja karyawan. Karyawan perlu mengembangkan karir mereka agar bisa naik jabatan dan memajukan tujuan perusahaan. Pengembangan karir yang terencana dan dilaksanakan secara baik akan memungkinkan organisasi/perusahaan menjadi unggul dalam lingkungan bisnis yang semakin kompetitif .

\section{Metodologi Penelitian}

\section{Objek Penelitian}

Penelitian ini di lakukan pada karyawan yang bekerja pada Rumah Sakit Umum Daerah Dr. Muhammad Zein Painan yang beralamatkan di Jl. Dr. A. Rivai Painan, Kabupaten Pesisir Selatan Sumatera Barat. 


\section{Desain Penelitian}

Pada penelitian ini menggunakan metode kuantitatif, menurut (Sugiyono, 2014), metode kuantitatif adalah metode yang berlandasan pada filsafat positifisme, digunakan untuk meneliti pada populasi dan sampel tertentu, pengumpulan data menggunakan instrumen penelitian, analisis data bersifat kuantitatif/statistik dengan tujuan untuk menguji hipotesis yang telah ditetapkan.

\section{Popupasi dan Sampel}

Menurut (Umar, 2013), populasi adalah wilayah generalisasi yang terdiri atas objek atau subjek yang mempunyai karakteristik tertentu dan mempunyai kesempatan yang sama untuk dipilih menjadi anggota sampel. Sedangkan sampel adalah bagian dari populasi yang mewakili populasi yang secara mutlak tidak diketahui berapa persentase sampel tersebut akan tetapi minimal 30 responden. Sampel yang digunakan untuk melakukan penelitian ini adalah 84 orang pegawai pada RSUD M. Zein Painan.

\section{Hasil Dan Pembahasan}

\section{Uji Validitas}

Pengujian menggunakan uji 2 sisi dengan tingkat signifikan 0,05, untuk menafsirkan hasil uji validitas, kriteria yang digunakan adalah:

1. Jika nilai $r_{\text {hitung }}$ lebih besar (>) dari nilai $r_{\text {tabel }}$, maka instrument atau item-item pertanyaan berkorelasi signifikan terhadap skor total, dinyatakan valid dan dapat dipergunakan.

2. Jika nilai $r_{\text {hitung }}$ lebih kecil $(<)$ dari nilai $r_{\text {tabel }}$, maka instrument atau item-item pertanyaan tidak berkorelasi signifikan terhadap skor total, dinyatakan tidak valid dan tidak dapat dipergunakan. Nilai tabel $\mathrm{r}$ dapat dilihat pada $\alpha=5 \%$.

Kriteria penilaian untuk validitas yang dipakai dalam penelitian yaitu: Instrumen-instrumen pada variabel Hubungan Kerja $\left(\mathrm{X}_{1}\right)$, Motivasi $\left(\mathrm{X}_{2}\right)$, Kompensasi $\left(\mathrm{X}_{3}\right)$, Pengembangan $\operatorname{Karier}\left(\mathrm{X}_{4}\right)$ dan Kinerja $(\mathrm{Y})$ dinyatakan valid karena nilai $\mathrm{r}_{\text {hitung }}$ lebih besar dari nilai $\mathrm{r}_{\text {tabel. }}$

\section{Uji Reliabilitas}

Dalam penelitian ini, untuk pengujin reliabilitas (kehandalan) instrument, penelitian menggunakan rumus Alpha Cronbach. Reliabilitas merupakan konsistensi dan stabilitas dari pengukuran instrument. Dengan demikian, reliabilitas mencakup dua hal utama yaitu stabilitas ukuran dan konsistensi internal ukuran. Kriteria penilaian untuk reliabilitas yang dipakai dalam penelitian yaitu: Setelah instrumen-instrumen pada variabel Hubungan Kerja $\left(\mathrm{X}_{1}\right)$, Motivasi $\left(\mathrm{X}_{2}\right)$, Kompensasi $\left(\mathrm{X}_{3}\right)$, Pengembangan $\operatorname{Karier}\left(\mathrm{X}_{4}\right)$ dan Kinerja $(\mathrm{Y})$ dinyatakan valid, maka selanjutnya dilakukan uji realiabilitas (kehandalan) pada masing-masing variabel. Dari pengujian reliabilitas variabel-variabel tersebut, diperoleh hasil yang dapat dilihat pada tabel sebagai berikut:

\section{Tabel Reliability Statistics}

\begin{tabular}{lcccc}
\hline \multicolumn{1}{c}{ Variabel } & $\begin{array}{c}\mathbf{N = 8 4} \\
\text { Jumlah item } \\
\text { pertanyaan }\end{array}$ & $\begin{array}{c}\text { Cronbach } \\
\text { alpha }\end{array}$ & & Repute of thumb \\
& 10 & 0,478 & 0,6 & Reliabel \\
\hline Hubungan Kerja $\left(\mathrm{X}_{1}\right)$ & 10 & 0,655 & 0,6 & Reliabel \\
Motivasi $\left(\mathrm{X}_{2}\right)$ & 10 & 0,672 & 0,6 & Reliabel \\
Kompensasi $\left(\mathrm{X}_{3}\right)$ & 10 & 0,636 & 0,6 & Reliabel \\
Pengembangan Karier $\left(\mathrm{X}_{4}\right)$ & 10 & 0,677 & 0,6 & Reliabel \\
Kinerja $(\mathrm{Y})$ & & & \\
\hline
\end{tabular}

Sumber:Hasil Pengolahan SPSS 21.0 windows Evaluation Version

Dari tabel di atas terlihat seluruh instrument berdasarkan analisis reliabilitas atas variabel penelitain menunjukkan bahwa nilai Cronbanch's alpha untuk beberapa variabel adalah di bawah 0,6 , untuk itu seluruh variabel bisa dikatakan reliabel (handal). 


\section{Hasil Uji Regresi Berganda}

Tabel 2. Analisis Regresi Linier Berganda

Coefficients $^{\mathrm{a}}$

\begin{tabular}{|c|c|c|c|c|c|c|}
\hline \multicolumn{2}{|c|}{ Model } & \multicolumn{2}{|c|}{ Unstandardized Coefficients } & \multirow{2}{*}{$\begin{array}{c}\text { Standardized } \\
\text { Coefficients } \\
\text { Beta }\end{array}$} & & \multirow[t]{2}{*}{ Sig. } \\
\hline & & $\mathrm{B}$ & Std. Error & & & \\
\hline & & & & $\mathrm{t}$ & & \\
\hline & (Constant) & 4.826 & 6.821 & & .708 & .481 \\
\hline & Hubungan_Kerja & .001 & .093 & .001 & .007 & .995 \\
\hline \multirow[t]{3}{*}{1} & Motivasi & .222 & .108 & .226 & 2.061 & .043 \\
\hline & Kompensasi & .409 & .106 & .421 & 3.845 & .000 \\
\hline & Pengembangan_Karir & .275 & .098 & .241 & 2.802 & .006 \\
\hline
\end{tabular}

a. Dependent Variable: Kinerja

Sumber:Hasil Pengolahan SPSS 21.0 windows Evaluation Version

Berdasarkan tabel 2 diatas maka dapat dilihat persamaan regresinya yaitu:

$$
\mathrm{Y}=4,826+0,001 \mathrm{X} 1+0,222 \mathrm{X} 2+0,409 \times 3+0,275 X 4+\mathrm{e}
$$

Dari persamaan diatas diketahui bahwa nilai konstanta sebesar 4,826. Jika hubungan kerja, motivasi, kompensasi dan pengembangan karier diabaikan, maka kinerja karyawan sebesar 4,826. Untuk variable independen Hubungan kerja memiliki nilai koefisien sebesar 0,001. Jika hubungan kerja ditingkatkan sebesar satu satuan, dengan asumsi motivasi, kompensasi dan pengembangan karier diabaikan, maka kinerja karyawan akan meningkat sebesar 0,001.

Variabel independen kedua yaitu motivasi memiliki nilai koefisien sebesar 0,222. Jika motivasi ditingkatkan sebesar satu satuan, dengan asumsi hubungan kerja, kompensasi dan pengembangan karir diabaikan, maka kinerja karyawan akan meningkat sebesar 0,222. Variabel independen ketiga yaitu kompensasi memiliki nilai koefisien sebesar 0,409. Jika kompensasi ditingkatkan sebesar satu satuan, dengan asumsi hubungan kerja, motivasi dan pengembangan karier diabaikan, maka kinerja karyawan akan meningkat sebesar 0,409 . Variabel berikutnya yaitu pengembangan karis memiliki nilai koefisien sebesar 0,275. Jika pengembangan karir ditingkatkan sebesar satu satuan, dengan asumsi hubungan kerja, motivasi dan kompensasi diabaikan, maka kinerja karyawan akan meningkat sebesar 0,275 .

Tabel 3. Pengujian Hipotesis Secara Simultan (Uji F) ANOVA $^{\mathrm{a}}$

\begin{tabular}{llrrrrr}
\hline Model & & Sum of & Df & Mean Square & F & Sig. \\
& & Squares & & & & \\
& Regression & 263.934 & 4 & 65.983 & 14.460 & $.000^{\mathrm{b}}$ \\
1 & Residual & 360.483 & 79 & 4.563 & & \\
& Total & 624.417 & 83 & & & \\
\hline
\end{tabular}

a. Dependent Variable: Kinerja

b. Predictors: (Constant), Pengembangan_Karir, Kompensasi, Hubungan_Kerja, Motivasi

Sumber : Hasil Pengolahan SPSS 21.0 Windows Evaluation Version

Dari tabel 3 di atas, dapat dilihat dengan tingkat signifikan 0,000 lebih kecil dari 0,05 maka diperoleh $\mathrm{H}_{\mathrm{o}}$ ditolak dan $\mathrm{H}_{\mathrm{a}}$ diterima, yang berarti hal ini dilakukan secara bersama-sama antara Hubungan Kerja, Motivasi, Kompensasi dan Pengembangan Karir berpengaruh signifikan terhadap Kinerja Karyawan. 


\section{Implikasi Penelitian}

Dari Berdasarkan hasil penelitian yang telah dilakukan, maka penulis dapat mengimplikasikan hal-hal sebagai berikut:

1. Pengaruh Hubungan Kerja (X1) Terhadap Kinerja Karyawan (Y)

Tidak Terdapat pengaruh yang signifikan antara hubungan kerja terhadap kinerja karyawan pada RSUD Dr. Muhammad Zein Painan karena tingkat signifikan lebih besar dari alpha 0,05 yaitu 0,995. Penelitian ini bertolak belakang dengan hasil penelitian (Ernawati, 2010) menyatakan bahwa hubungan kerja memberi pengaruh terhadap kinerja karyawan, karena hubungan kerja sangat membantu dalam meningkatkan kinerja karyawan.

2. Pengaruh Motivasi (X2) Terhadap Kinerja Karyawan (Y)

Terdapat pengaruh yang signifikan antara motivasi terhadap kinerja karyawan pada RSUD Dr. Muhammad Zein Painan karena tingkat signifikan lebih kecil dari alpha 0,05 yaitu 0,043. Penelitian ini sejalan dengan hasil penelitian (Gusnita, 2012)menyatakan bahwa motivasi memberi pengaruh terhadap kinerja karyawan.

3. Pengaruh Kompensasi (X3) Terhadap Kinerja Karyawan (Y)

Terdapat pengaruh yang signifikan antara kompensasi terhadap kinerja karyawan pada RSUD Dr. Muhammad Zein Painan karena tingkat signifikan lebih kecil dari alpha 0,05 yaitu 0,000. Penelitian ini sejalan dengan hasil penelitian (Utami, 2018).

4. Pengaruh Pengembangan Karir (X4) Terhadap Kinerja Karyawan (Y)

Terdapat pengaruh yang signifikan antara pengembangan karir terhadap kinerja karyawan pada RSUD Dr. Muhammad Zein Painan karena tingkat signifikan lebih kecil dari alpha 0,05 yaitu 0,006. Penelitian ini sejalan dengan hasil penelitian (Syaiful Bahri, 2017).

5. Pengaruh Hubungan Kerja, Motivasi, Kompensasi, dan Pengembangan Karir Terhadap Kinerja Karyawan (Y)

Secara simultan terdapat pengaruh yang signifikan antara hubungan kerja, motivasi, kompensasi dan pengebangan karir terhadap kinerja karyawan pada RSUD Dr. Muhammad Zein Painan karena tingkat signifikan lebih kecil dari alpha 0.05 yaitu 0.000 . Penelitian ini sejalan dengan hasil penelitian (Lakoy, 2013).

\section{Kesimpulan}

Berdasarkan hasil penelitian yang dikemukakan pada bab sebelumnya maka dapat disimpulkan beberapa hal dalam penelitian ini : Bahwa tidak terdapat pengaruh Hubungan Kerja terhadap Kinerja Karyawan pada RSUD Dr. Muhammad Zein Painan, dan terdapat pengaruh Motivasi terhadap Kinerja Karyawan pada RSUD Dr. Muhammad Zein Painan. Pada RSUD Dr. Muhammad Zein Painan terdapat pengaruh Kompensasi terhadap Kinerja Karyawan, dan terdapat pengaruh Karier terhadap Kinerja Karyawan pada RSUD Dr. Muhammad Zein Painan. Secara bersama-sama terdapat pengaruh yang signifikan antara Hubungan Kerja, Motivasi, Kompensasi dan Pengembangan Karir terhadap Kinerja Karyawan pada RSUD Dr. Muhammad Zein Painan.

\section{Daftar Pustaka}

[1] Ardana, I. K. Manajemen Sumber Daya Manusia. Yogyakarta: Graha Ilmu. 2012.

[2] Didit, D. Prinsip-Prinsip Perilaku Organisasi. Surabaya: Pt. Temprina Media Grafika. 2013.

[3] Ernawati. Pengaruh Hubungan Kerja Dan Lingkungan Kerja Terhadap Kinerja Pegawai Dengan Motivasi Kerja Sebagai Varibel Moderating. Jurnal Ekonomi Dan Kewirausahaan, Vol. 10, No. 2, Oktober : $100-112.2010$.

[4] Gunawan, A. Pengaruh Kompensasi Dan Pengembangan Karir Terhadap Kepuasan Kerja Perawat Yang Dimediasi Oleh Motivasi Kerja Pada Rumah Sakit Bina Kasih Pekanbaru. Jom Fekon , Vol. 4 No. 1. 2017.

[5] Gusnita, N. Pengaruh Motivasi Dan Ability Terhadap Kinerja Karyawan Pt. Jasa Raharja (Persero) Cabang Riau,. Jurnal Ekonomi Manajemen, Hal 1-18. Volume 6. No 2. Maret 2012.

[6] Hasibuan, M. Manajemen Sumber Daya Manusia. Jakarta: Bumi Aksara. 2014.

[7] Kadarisman. Manajemen Pengembngan Sumberdaya Manusia. Jakarta: Rajawali Pers. 2014. 
[8] Lakoy, G. F. Motivasi Kerja, Kompensasi, Pengembangan Karir Terhadap Kinerja Pegawai Pada Badan Penanggulangan Bencana Daerah Provinsi Sulawesi Utara. Jurnal Emba , Vol.1 No.4 Desember, Hal. 771-781.2013.

[9] Rivai, V. Manajemen Sumber Daya Manusia Untuk Perusahaan. Jakarta Utara: Raja Grafindo Persada. 2011.

[10] Sagala, R. D. Manajemen Sumber Daya Manusia Untuk Perusahaan. Jakarta: Edisi Kedua Pt. Raja Grafindo Persada. 2009.

[11] Siagian, S. Manajemen Sumber Daya Manusia. Jakarta: Bumi Aksara. 2015.

[12] Sofyand, H. Manajemen Sumber Daya Manusia. Yogyakarta: Cetakan Kedua Graha Ilmu. 2013.

[13] Sugiyono. Metode Penelitian Kuantitatif Kualitatif Dan R\&D. Bandung: Alfabeta. 2014.

[14] Syaiful Bahri, Y. C. Pengaruh Pengembangan Karir Dan Motivasi Kerja Terhadap Kepuasan Kerja Karyawan. Jurnal Ilmiah Manajemen \& Bisnis , Vol. 18 No. 1, 9-15. 2017.

[15] Umar, H. Metode Penelitian Untuk Skripsi Dan Tesis Bisnis. Jakarta: PT. Raja Grafindo Persada. 2013.

[16] Utami, E. N. (2018). Pengaruh Kompensasi Dan Pengembangan Karir Terhadap Organizational Citizenship Behavior (OCB) . Jurnal Administrasi Bisnis (JAB), Vol. 55 No. 1 Februari 2018. 